\title{
Synthesis and Biological Activities of Novel 1,7-dihydropyrazolo[3,4-d] imidazo[1,2-f]pyrimidines
}

\section{Amine Karoui ${ }^{1}$, Monia Deghrigue ${ }^{2}$, Gilbert Kirsch ${ }^{3}$, Abderrahman Bouraoui $^{2}$, Fakher Chabchoub ${ }^{1}$ and Fatma Allouche ${ }^{\star *}$}

${ }^{1}$ Laboratoire de Chimie Appliquée, Hétérocycles, Corps Gras et Polymères, Faculté des Sciences de Sfax, Université de Sfax, 3018 Sfax, Tunisie ${ }^{2}$ Laboratoire de développement chimique, galénique et pharmacologique des médicaments (LR12ESO9). Equipe de Pharmacologie marine, Faculté de pharmacie de Monastir, Université de Monastir, 5000 Monastir, Tunisie

${ }^{3}$ Laboratoire d'Ingénierie Moléculaire et Biochimie Pharmacologique (EA3940), Institut Jean Barriol, Université de Lorraine, Metz, France

\begin{abstract}
A straightforward method has been developed for the synthesis of new anti-inflammatory 1,7-dihydropyrazolo[3,4- $d$ ] imidazo[1,2-f]pyrimidine 5 from aminocyanopyrazole. These compounds were screened for their anti-inflammatory, gastroprotective, analgesic, antioxidant and anticandidal activities. Studies of structure-activity relationships have led to selection of compound 6-(4-methoxyphenyl)-3-methyl-1,7-dihydropyrazolo[3,4- $d$ ]imidazo[1,2-f]pyrimidine, 5a which exhibited the most potent activities. The structures of all new compounds were elucidated using IR, ${ }^{1} \mathrm{H}$ NMR, ${ }^{13} \mathrm{C}$ NMR and HRMS.
\end{abstract}

Keywords: Anti-inflammatory; Gastroprotective; Antioxidant; Anticandidal; Analgesic; Pyrazolo[3,4- $d]$ pyrimidine, 1,7-dihydropyrazolo[3,4-d]imidazo[1,2-f]pyrimidines

\section{Introduction}

The growing incidence of drug-resistant infection diseases has stimulated the need for the development of new drugs. Since the few last decades, synthetic chemistry has been recognized to be rich source of bioactive metabolites with varied biological and pharmacological activities. Currently, Non-steroidal anti-inflammatory drugs (NSAIDs) are used throughout the world for the treatment of inflammation, pain and fever; however most of these produce several adverse reactions such as ulcers and hemorrhage [1]. In addition, reactive oxygen species (ROS) and free radicals play important roles in degenerative or pathological processes leading to many health disorders including inflammatory and cancer diseases [2]. The harmful effect of the free radicals can however, be blocked by synthetic antioxidants such as butylated hydroxytoluene (BHT), butylated hydroxyanisole (BHA), tert-butylhydroquinone (TBHQ) and propyl gallate (PG) [3]. However, due to their adverse side effects, search for more effective antioxidants has become crucial. Pyrazolopyrimidines, class of sedative and anxiolytic drugs [4], and its derivatives constitute a rich source of a wide variety of structurally unusual metabolites and seem to be an endless source of new chemical constituents.

In order to determine the role of methyl group and methoxy group of pyrazolopyrimidines in the antioxidant, anti-inflammatory, gastroprotective, analgesic and anticandidal activities, we have synthesized new 1,7-dihydropyrazolo[3,4- $d]$ imidazo[1,2-f] pyrimidines 5 and evaluate their pharmacological activities. Interestingly, we found that the activity of new compounds is dependent on the location of the methyl and methoxy group. Our results provided new evidence for the relationship between chemical structure and pharmacological activities as the case of $5 \mathrm{a}$ and $5 \mathrm{~b}$.

\section{Materials and Methods}

\section{Chemistry}

Phenyl hydrazine, malononitrile, triethylorthoester, ammoniac, a-Bromoacetophenone, PTSA, $\mathrm{CH}_{3} \mathrm{COOH}$ and solvents used in this work were obtained from Aldrich and Fluka and were used without further purification.

Melting points were measured on an Electrothermal apparatus.
Progress of their actions was monitored with TLC using aluminium sheets with silica gel 60 F254 from Merck. Spectra IR were recorded on a Perkin-Elmer PARAGON FT-IR spectrometer covering field $400-4000 \mathrm{~cm}^{-1}$. The spectra of ${ }^{1} \mathrm{H}$ NMR and ${ }^{13} \mathrm{C}$ NMR was recorded in solution in $\mathrm{CDCl}_{3}$ or in dimethylsulfoxide (DMSO- $\mathrm{d}_{6}$ ) on a Bruker spectrometer $\left({ }^{1} \mathrm{H}\right.$ at $400 \mathrm{MHz},{ }^{13} \mathrm{C}$ at $\left.100 \mathrm{MHz}\right)$ and High resolution mass spectrometry (HRMS). The chemical shifts are expressed in parts per million (ppm) by using tetramethylsilane (TMS) as internal reference. The multiplicities of the signals were indicated by the following abbreviations: $\mathrm{s}$, singlet; $\mathrm{d}$, doublet; $\mathrm{t}$, triplet; $\mathrm{q}$, quadruplet; $\mathrm{m}$, multiplet, and coupling constants are expressed in Hertz.

Synthesis and spectral data of compounds 2-5: The general synthetic procedure employed for 1,7-dihydropyrazolo[3,4- $d]$ imidazo[1,2- $f$ pyrimidines 5 are outlined in Scheme 1.

5-amino-4-cyano- $N^{I}$-phenyl pyrazoles (2): 5-Amino-4-cyano$1-N^{1}$-phenyl pyrazoles prepared via a standard addition of hydrazine derivatives to ketene ethoxymethylene compounds following the reported procedure. Recrystallization from ethanol afforded pure 2 in good yields $[5,6]$.

4-cyano- $N^{I}$-phenyl pyrazolo-5-imidates (3): The required 5 -amino-4-cyano- $N^{1}$-phenyl pyrazole $(1.0 \mathrm{mmol})$ was treated with triethylorthoester $(6.0 \mathrm{mmol})$ and a catalytic amount of acetic acid and the mixture was refluxed for $24 \mathrm{~h}$. After cooling, the reaction mixture was evaporated. The product was filtered, washed with diethyl ether then purified by recrystallization (ethanol).

4-amino- $N^{1}$-phenyl pyrazolo[3,4-d] pyrimidine (4): A solution of imidate $3(1.0 \mathrm{mmol})$ in dry ethanol $(5 \mathrm{~mL})$ was treated with ammoniac $(2.0 \mathrm{mmol})$ and a catalytic amount of acetic acid. The reaction mixture

*Corresponding author: Fatma Allouche, Laboratoire de Chimie Appliquée, Hétérocycles, Corps Gras et Polymères, Faculté des Sciences de Sfax, Université de Sfax, 3018 Sfax, Tunisie, Tel: +21626299719; Fax: +21674676606; E-mail: fatmaallouch@yahoo.fr

Received March 05, 2016; Accepted March 21, 2016; Published March 24, 2016

Citation: Karoui A, Deghrigue M, Kirsch G, Bouraoui A, Chabchoub F, et al (2016) Synthesis and Biological Activities of Novel 1,7-dihydropyrazolo[3,4- $d$ ] imidazo[1,2-ffpyrimidines. Med chem (Los Angeles) 6: 157-164. doi:10.4172/21610444.1000340

Copyright: $\odot 2016$ Karoui A, et al. This is an open-access article distributed under the terms of the Creative Commons Attribution License, which permits unrestricted use, distribution, and reproduction in any medium, provided the original author and source are credited. 
<smiles>[R]C(=Nc1c(C#N)c([R])nn1-c1ccccc1)OCC</smiles><smiles>[R2]C([R2])C([R])C</smiles><smiles>[R2]c1nc(N)c2c([R])nn(-c3ccccc3)c2n1</smiles>

reagents: $\mathrm{i} / \mathrm{H}_{2} \mathrm{~N}-\mathrm{NHPh}, \mathrm{H}_{2} \mathrm{SO}_{4}, \mathrm{ii} / \mathrm{R}_{2} \mathrm{CH}(\mathrm{OEt})_{3}, \mathrm{H}_{2} \mathrm{SO}_{4}$, iii/ $\mathrm{NH}_{3}$<smiles>[R3]c1ccc(C(=O)CBr)cc1</smiles>

Scheme 1: Synthetic procedure of 1,7-dihydropyrazolo[3,4-d]imidazo[1,2-f]pyrimidines 5a-i.

was refluxed for $6 \mathrm{~h}$, and the formed solid was collected by filtration, dried and recrystallized from ethanol to give compound 4.

a) 4-amino- $N^{1}$-phenyl-1H-pyrazolo $[3,4-d]$ pyrimidine 4a: Yield $83 \%$; mp $228{ }^{\circ} \mathrm{C}$; IR $\left(\mathrm{cm}^{-1}\right): v_{\mathrm{NH} 2} 3100,3283 ; v_{\mathrm{C}=\mathrm{N}} 1480,1500$, $1590 \mathrm{~cm}^{-1} ; \mathrm{RMN}^{1} \mathrm{H}\left(\delta \mathrm{ppm}, \mathrm{DMSO}-\mathrm{d}_{6}\right): 4.69\left(2 \mathrm{H}, \mathrm{s}, \mathrm{NH}_{2}\right), 7.36(1 \mathrm{H}$, t, $\left.J=7.3 \mathrm{~Hz}, \mathrm{ArH}_{4}\right), 7.48\left(2 \mathrm{H}, \mathrm{t}, J=7.3 \mathrm{~Hz}, \mathrm{ArH}_{3}\right.$ and $\left.\mathrm{ArH}_{5}\right), 7.52(2 \mathrm{H}, \mathrm{d}$, $J=7.3 \mathrm{~Hz}, \mathrm{ArH}_{2}$ and $\left.\mathrm{ArH}_{6}\right), 7.60\left(1 \mathrm{H}, \mathrm{s}, \mathrm{H}_{3}\right), 7.72\left(1 \mathrm{H}, \mathrm{s}, \mathrm{H}_{6}\right),{ }^{13} \mathrm{C} \mathrm{RMN}$ $\left(\delta \mathrm{ppm}, \mathrm{DMSO}-\mathrm{d}_{6}\right): 114.14$ (C-3a), 124.27 (C-2' and C-6'), 129.00 (C-4'), 129.58 (C-3' and C-5'), 130.04 (C-3), 136.94 (C-1'), 141.36 (C-7a), 149.83 (C-6), 156.84 (C-4); HRMS Calculated for $\mathrm{C}_{11} \mathrm{H}_{9} \mathrm{~N}_{5}$ : 211.0858, found: 211.0859 .

B) 4-amino-3-methyl- $N^{1}$-phenyl- $1 H$-pyrazolo $[3,4-d]$ pyrimidine 4b: Yield $68 \%$; mp $192{ }^{\circ} \mathrm{C}$; IR $\left(\mathrm{cm}^{-1}\right) v_{\mathrm{NH} 2}: 3083,3317, v_{\mathrm{C}=\mathrm{N}}$ $1626,1647,1665 ; \mathrm{RMN}^{1} \mathrm{H}\left(\delta \mathrm{ppm}, \mathrm{DMSO}-\mathrm{d}_{6}\right): 2.76\left(3 \mathrm{H}, \mathrm{s}, \mathrm{CH}_{3}\right), 5.97$ $\left(2 \mathrm{H}, \mathrm{s}, \mathrm{NH}_{2}\right), 7.33\left(1 \mathrm{H}, \mathrm{t}, J=7.1 \mathrm{~Hz}, \mathrm{ArH}_{4}\right), 7.57\left(2 \mathrm{H}, \mathrm{t}, J=7.1 \mathrm{~Hz}, \mathrm{ArH}_{3}\right.$ and $\left.\mathrm{ArH}_{5}\right), 8.16\left(2 \mathrm{H}, \mathrm{d}, J=7.1 \mathrm{~Hz}, \mathrm{ArH}_{2}\right.$ and $\left.\mathrm{ArH}_{6}\right), 8.46\left(1 \mathrm{H}, \mathrm{s}, \mathrm{H}_{3}\right)$; $\mathrm{RMN}^{13} \mathrm{C}\left(\delta \mathrm{ppm}, \mathrm{DMSO}-\mathrm{d}_{6}\right): 14.89\left(\mathrm{CH}_{3}\right), 101.23(\mathrm{C}-3 \mathrm{a}), 121.49\left(\mathrm{C}-2^{\prime}\right.$ and C-6'), 126.37 (C-4'), 129.19 (C-3' and C-5'), 138.81 (C-3), 141.83 (C-1'), 154.41 (C-7a), 156.48 (C-4), 158.40 (C-6); HRMS Calculated for $\mathrm{C}_{12} \mathrm{H}_{11} \mathrm{~N}_{5}: 225.1014$, found: 225.1018 .

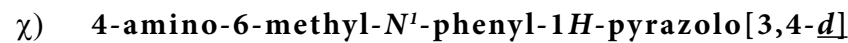
pyrimidine 4c: Yield $70 \%$; mp $160^{\circ} \mathrm{C}$; IR $\left(\mathrm{cm}^{-1}\right) v_{\mathrm{NH} 2}: 3090,3320 ; v_{\mathrm{C}=\mathrm{N}}$ 1597, 1638, 1663; RMN ${ }^{1} \mathrm{H}\left(\delta \mathrm{ppm}, \mathrm{DMSO}-\mathrm{d}_{6}\right): 2.65\left(3 \mathrm{H}, \mathrm{s}, \mathrm{CH}_{3}\right), 4.28$ $\left(2 \mathrm{H}, \mathrm{s}, \mathrm{NH}_{2}\right), 7.28\left(1 \mathrm{H}, \mathrm{t}, J=7.3 \mathrm{~Hz}, \mathrm{ArH}_{4}\right), 7.56\left(2 \mathrm{H}, \mathrm{t}, J=7.3 \mathrm{~Hz}, \mathrm{ArH}_{3}\right.$ and $\left.\mathrm{ArH}_{5}\right), 8.19\left(2 \mathrm{H}, \mathrm{d}, J=7.3 \mathrm{~Hz}, \mathrm{ArH}_{2}\right.$ and $\left.\mathrm{ArH}_{6}\right), 8.29\left(1 \mathrm{H}, \mathrm{s}, \mathrm{H}_{6}\right)$; $\mathrm{RMN}^{13} \mathrm{C}(\delta$ ppm, DMSO-d 6$): 14.44\left(\mathrm{CH}_{3}\right), 100.24(\mathrm{C}-3 \mathrm{a}), \mathrm{C}_{\text {arom }} 120.24$
(C-2' and C-6'), 124.67 (C-4'), 129.16 (C-3' and C-5'), 138.80 (C-3), 142.79 (C-1'); C 154.14 (C-7a), 156.51 (C-4), 158.58 (C-6); HRMS Calculated for $\mathrm{C}_{12} \mathrm{H}_{11} \mathrm{~N}_{5}: 225.1014$, found: 225.1016 .

1,7-dihydropyrazolo[3,4-d]imidazo[1,2-f]pyrimidines 5a-i: To a mixture of 4 -amino- $N^{1}$-phenyl- $1 H$-pyrazolo[3,4- $d$ ] pyrimidine 4 ( $1 \mathrm{mmol}$ ) and $\alpha$-bromoacetophenone $(1 \mathrm{mmol})$ in $3 \mathrm{~mL}$ of ethanol, was added $\mathrm{p}$-TsOH (5\%) then refluxed for $12 \mathrm{~h}$. After completion of the reaction, as indicated by TLC (EtOAc-hexane, 90:10), the precipitate product was separated by filtration and washed with ethanol and was crystallized from a suitable solvent to obtain pure product.

a) 6-(4-methoxyphenyl)-3-methyl- $N^{1}$-phenyl-1,7dihydropyrazolo $[3,4-d]$ imidazo[1,2-f]pyrimidine 5a: Yield $74 \%$; mp $210^{\circ} \mathrm{C}$; IR $\left(\mathrm{cm}^{-1}\right): v_{\mathrm{C}=\mathrm{N}} 1505,1542,1593$; RMN ${ }^{1} \mathrm{H}\left(\delta \mathrm{ppm}, \mathrm{DMSO}-\mathrm{d}_{6}\right)$ : $2.80\left(3 \mathrm{H}, \mathrm{s}, \mathrm{CH}_{3}\right) ; 3.84\left(3 \mathrm{H}, \mathrm{s}, \mathrm{CH}_{3}\right) ; 7.07\left(2 \mathrm{H}, \mathrm{d}, J=8.7 \mathrm{~Hz}, \mathrm{ArH}_{3}{ }^{\prime}\right.$ and $\left.\mathrm{ArH}_{5}{ }^{\prime}\right) ; 7.39\left(1 \mathrm{H}, \mathrm{t}, J=7.2 \mathrm{~Hz}, \mathrm{ArH}_{4}\right) ; 7.60\left(2 \mathrm{H}, \mathrm{t}, J=5.4 \mathrm{~Hz}, \mathrm{ArH}_{3}\right.$ and $\left.\operatorname{ArH}_{5}\right) ; 7.95\left(2 \mathrm{H}, \mathrm{d}, J=8.7 \mathrm{~Hz}, \mathrm{ArH}_{2}\right.$ and $\left.\mathrm{ArH}_{6}\right) ; 8.15(2 \mathrm{H}, \mathrm{d}, J=7.8 \mathrm{~Hz}$, $\mathrm{ArH}_{2}$ ' and $\left.\mathrm{ArH}_{6}{ }^{\prime}\right) ; 8.42\left(1 \mathrm{H}, \mathrm{s}, \mathrm{H}_{5}\right) ; 9.29\left(1 \mathrm{H}, \mathrm{s}, \mathrm{H}_{8}\right) . \mathrm{RMN}^{13} \mathrm{C}(\delta \mathrm{ppm}$, DMSO-d $\left.{ }_{6}\right): 14.37\left(\mathrm{CH}_{3}\right) ; 55.17\left(\mathrm{CH}_{3}\right) ; 106.62(\mathrm{C}-3 \mathrm{a}) ; 114.23(\mathrm{C}-3$ " and C-5"), 121.22 (C-5), 121.28 (C-3' and C-5'), 125.22 (C-6), 126.52 (C-1"), 126.79 (C-4'), 127.14 (C-2" and C-6”), 129.18 (C-2' and C-6'), 139.80 (C-1'), 140.20 (C-8), 142.20 (C-4a), 151.35 (C-3), 154.57 (C-9a), 159.35 (C-4"); HRMS Calculated for $\mathrm{C}_{21} \mathrm{H}_{17} \mathrm{~N}_{5} \mathrm{O}: 355.1433$, found: 355.1489 .

b) 6 - ( 4 - m e thoxy phenyl) - $N^{1}$ - phe ny $1-1,7$ dihydropyrazolo $[3,4-d]$ imidazo $[1,2-f]$ pyrimidine 5 b: Yield $78 \%$; mp $171^{\circ} \mathrm{C}$; IR $\left(\mathrm{cm}^{-1}\right): v_{\mathrm{C}=\mathrm{N}} 1511,1575,1595 ; \mathrm{RMN}^{1} \mathrm{H}\left(\delta \mathrm{ppm}, \mathrm{DMSO}-\mathrm{d}_{6}\right)$ : $3.82\left(3 \mathrm{H}, \mathrm{s}, \mathrm{CH}_{3}\right) ; 7.09\left(2 \mathrm{H}, \mathrm{d}, J=7.2 \mathrm{~Hz}, \mathrm{ArH}_{3}{ }^{\prime}\right.$ and $\left.\mathrm{ArH}_{5}{ }^{\prime}\right) ; 7.46(1 \mathrm{H}$, 
$\left.\mathrm{t}, J=7.5 \mathrm{~Hz}, \mathrm{ArH}_{4}\right) ; 7.63\left(2 \mathrm{H}, \mathrm{t}, J=8.4 \mathrm{~Hz}, \mathrm{ArH}_{3}\right.$ and $\left.\mathrm{ArH}_{5}\right) ; 7.94(2 \mathrm{H}, \mathrm{d}$, $J=8.7 \mathrm{~Hz}, \mathrm{ArH}_{2}$ and $\left.\mathrm{ArH}_{6}\right) ; 8.13\left(2 \mathrm{H}, \mathrm{d}, J=8.0 \mathrm{~Hz}, \mathrm{ArH}_{2}^{\prime}\right.$ and $\left.\mathrm{ArH}_{6}^{\prime}\right)$; $8.54\left(1 \mathrm{H}, \mathrm{s}, \mathrm{H}_{5}\right) ; 8.69\left(1 \mathrm{H}, \mathrm{s}, \mathrm{H}_{3}\right) ; 8.41\left(1 \mathrm{H}, \mathrm{s}, \mathrm{H}_{8}\right) . \mathrm{RMN}^{13} \mathrm{C}(\delta \mathrm{ppm}$, DMSO-d $\left.)_{6}\right): 55.26\left(\mathrm{CH}_{3}\right) ; 107.50$ (C-3a); $114.14(\mathrm{C}-3 "), 114.49$ (C-5"), 121.79 (C-5), 121.86 (C-3' and C-5'), 122.67 (C-6), 127.27 (C-1"), 127.38 (C-4'), 128.73 (C-2" and C-6"), 129.36 (C-2' and C-6'), 133.02 (C-3), 138.13 (C-1'), 139.06 (C-8), 139.95 (C-4a), 144.87 (C-9a), 159.79 (C-4"); HRMS Calculated for $\mathrm{C}_{20} \mathrm{H}_{15} \mathrm{~N}_{5} \mathrm{O}: 341.1277$, Found: 341.1341 .

c) 6-p-tolyl- $N^{1}$-phenyl-1,7-dihydropyrazolo $[3,4-d]$ imidazo[1,2-f]pyrimidine 5c: Yield $81 \%$; mp $166^{\circ} \mathrm{C}$; IR $\left(\mathrm{cm}^{-1}\right): v_{\mathrm{C}=\mathrm{N}}$ $1519,1550,1594 ; \mathrm{RMN}^{1} \mathrm{H}\left(\delta \mathrm{ppm}, \mathrm{DMSO}-\mathrm{d}_{6}\right): 2.37\left(3 \mathrm{H}, \mathrm{s}, \mathrm{CH}_{3}\right)$; $7.04\left(2 \mathrm{H}, \mathrm{d}, J=8.4 \mathrm{~Hz}, \mathrm{ArH}_{3}{ }^{\prime}\right.$ and $\left.\mathrm{ArH}_{5}{ }^{\prime}\right) ; 7.34\left(1 \mathrm{H}, \mathrm{t}, J=7.5 \mathrm{~Hz}, \mathrm{ArH}_{4}\right)$; $7.61\left(2 \mathrm{H}, \mathrm{t}, J=5.9 \mathrm{~Hz}, \mathrm{ArH}_{3}\right.$ and $\left.\mathrm{ArH}_{5}\right) ; 7.92\left(2 \mathrm{H}, \mathrm{d}, J=6.0 \mathrm{~Hz}, \mathrm{ArH}_{2}\right.$ and $\left.\mathrm{ArH}_{6}\right) ; 8.13\left(2 \mathrm{H}, \mathrm{d}, J=7.5 \mathrm{~Hz}, \mathrm{ArH}_{2}{ }^{\prime}\right.$ and $\left.\mathrm{ArH}_{6}{ }^{\prime}\right) ; 8.56\left(1 \mathrm{H}, \mathrm{s}, \mathrm{H}_{5}\right) ; 8.71$ $\left(1 \mathrm{H}, \mathrm{s}, \mathrm{H}_{3}\right) ; 9.42\left(1 \mathrm{H}, \mathrm{s}, \mathrm{H}_{8}\right) . \mathrm{RMN}^{13} \mathrm{C}\left(\delta \mathrm{ppm}, \mathrm{DMSO}-\mathrm{d}_{6}\right): 21.38\left(\mathrm{CH}_{3}\right)$; 108.63 (C-3a); 120.35 (C-5); 121.67 (C-3' and C-5'), 122.45 (C-6), 126.23 (C-4'), 127.83 (C-2" and C-6"), 129.85 (C-3" and C-5"), 129.89 (C-2' and C-6'), 130.06 (C-1"), 136.45 (C-3), 138.70 (C-4"), 139.54 (C1'), 141.50 (C-8), 145.25 (C-4a), 149.10 (C-9a); HRMS Calculated for $\mathrm{C}_{20} \mathrm{H}_{15} \mathrm{~N}_{5}: 325.1327$, found: 325.1364 .

d) 6-p-tolyl-3-methyl- $N^{1}$-phenyl-1,7-dihydropyrazolo[3,4-d] imidazo[1,2-f]pyrimidine 5d: Yield $69 \%$; mp $206{ }^{\circ} \mathrm{C}$; IR $\left(\mathrm{cm}^{-1}\right): v_{\mathrm{C}=\mathrm{N}}$ $1519,1550,1594 ; \mathrm{RMN}^{1} \mathrm{H}\left(\delta \mathrm{ppm}, \mathrm{DMSO}-\mathrm{d}_{6}\right): 2.28\left(3 \mathrm{H}, \mathrm{s}, \mathrm{CH}_{3}\right)$; $2.36\left(3 \mathrm{H}, \mathrm{s}, \mathrm{CH}_{3}\right) ; 7.05\left(2 \mathrm{H}, \mathrm{d}, J=7.5 \mathrm{~Hz}, \mathrm{ArH}_{3}{ }^{\prime}\right.$ and $\left.\mathrm{ArH}_{5}{ }^{\prime}\right) ; 7.40(1 \mathrm{H}$, t, $\left.J=8.5 \mathrm{~Hz}, \mathrm{ArH}_{4}\right) ; 7.59\left(2 \mathrm{H}, \mathrm{t}, J=5.4 \mathrm{~Hz}, \mathrm{ArH}_{3}\right.$ and $\left.\mathrm{ArH}_{5}\right) ; 7.92(2 \mathrm{H}, \mathrm{d}$, $J=6.3 \mathrm{~Hz}, \mathrm{ArH}_{2}$ and $\left.\mathrm{ArH}_{6}\right) ; 8.01\left(2 \mathrm{H}, \mathrm{d}, J=5.1 \mathrm{~Hz}, \mathrm{ArH}_{2}{ }^{\prime}\right.$ and $\left.\mathrm{ArH}_{6}{ }^{\prime}\right) ; 8.51$ $\left(1 \mathrm{H}, \mathrm{s}, \mathrm{H}_{5}\right) ; 9.34\left(1 \mathrm{H}, \mathrm{s}, \mathrm{H}_{8}\right) . \mathrm{RMN}^{13} \mathrm{C}\left(\delta \mathrm{ppm}, \mathrm{DMSO}-\mathrm{d}_{6}\right): 14.90\left(\mathrm{CH}_{3}\right)$; $21.39\left(\mathrm{CH}_{3}\right) ; 108.02(\mathrm{C}-3 \mathrm{a}) ; 120.95(\mathrm{C}-5) ; 121.76\left(\mathrm{C}-3^{\prime}\right.$ and $\left.\mathrm{C}-5^{\prime}\right)$, 122.24 (C-6), 126.23 (C-4'), 127.09 (C-2" and C-6"), 129.50 (C-3" and C-5"), 129.88 (C-2' and C-6'), 130.10 (C-1"), 138.19 (C-4"), 139.35 (C1'), 140.41 (C-8), 142.77 (C-3), 145.48 (C-4a), 149.53 (C-9a); HRMS Calculated for $\mathrm{C}_{21} \mathrm{H}_{17} \mathrm{~N}_{5}$ : 339.1484 , found: 339.1421 .

e) 6-(4-methoxyphenyl)-8-methyl- $N^{1}$ - phenyl-1,7dihydropyrazolo $[3,4-d]$ imidazo $[1,2-f]$ pyrimidine $5 \mathrm{e}$ : Yield $62 \%$; mp $212^{\circ} \mathrm{C}$; IR $\left(\mathrm{cm}^{-1}\right): v_{\mathrm{C}=\mathrm{N}} 1500,1526,1594 ; \mathrm{RMN}^{1} \mathrm{H}\left(\delta \mathrm{ppm}, \mathrm{DMSO}-\mathrm{d}_{6}\right)$ : $2.78\left(3 \mathrm{H}, \mathrm{s}, \mathrm{CH}_{3}\right) ; 3.86\left(3 \mathrm{H}, \mathrm{s}, \mathrm{CH}_{3}\right) ; 7.02\left(2 \mathrm{H}, \mathrm{d}, J=7.3 \mathrm{~Hz}, \mathrm{ArH}_{3}{ }^{\prime}\right.$ and $\left.\mathrm{ArH}_{5}{ }^{\prime}\right) ; 7.41\left(1 \mathrm{H}, \mathrm{t}, J=7.5 \mathrm{~Hz}, \mathrm{ArH}_{4}\right) ; 7.68\left(2 \mathrm{H}, \mathrm{t}, J=5.4 \mathrm{~Hz}, \mathrm{ArH}_{3}\right.$ and $\left.\mathrm{ArH}_{5}\right) ; 8.03\left(2 \mathrm{H}, \mathrm{d}, J=7.8 \mathrm{~Hz}, \mathrm{ArH}_{2}\right.$ and $\left.\mathrm{ArH}_{6}\right) ; 8.21(2 \mathrm{H}, \mathrm{d}, J=7.5 \mathrm{~Hz}$, $\mathrm{ArH}_{2}^{\prime}$ and $\left.\mathrm{ArH}_{6}{ }^{\prime}\right) ; 8.39\left(1 \mathrm{H}, \mathrm{s}, \mathrm{H}_{5}\right) ; 8.87\left(1 \mathrm{H}, \mathrm{s}, \mathrm{H}_{3}\right) . \mathrm{RMN}^{13} \mathrm{C}(\delta \mathrm{ppm}$, DMSO-d $)_{6}$ : $14.21\left(\mathrm{CH}_{3}\right) ; 55.43\left(\mathrm{CH}_{3}\right) ; 106.58$ (C-3a); 114.64 (C-3" and C-5”); 121.36 (C-5), 121.45 (C-3' and C-5'), 125.51 (C-6), 126.64 (C-1"), 126.81 (C-4'), 127.22 (C-2" and C-6"), 129.18 (C-2' and C-6'), 133.19 (C-3), 139.74 (C-1'), 142.68 (C-4a), 153.76 (C-9a), 159.82 (C4"), 162.17 (C-8); HRMS Calculated for $\mathrm{C}_{21} \mathrm{H}_{17} \mathrm{~N}_{5} \mathrm{O}$ : 355.1433 , found: 355.1457 .

f) 6-p-tolyl-8-methyl- $N^{I}$-phenyl-1,7-dihydropyrazolo[3,4-d] imidazo[1,2-f]pyrimidine 5f: Yield $58 \%$; mp $205^{\circ} \mathrm{C}$; IR $\left(\mathrm{cm}^{-1}\right): v_{\mathrm{C}=\mathrm{N}}$ 1512, 1557, 1596; RMN ${ }^{1} \mathrm{H}\left(\delta \mathrm{ppm}, \mathrm{DMSO}-\mathrm{d}_{6}\right): 2.29\left(3 \mathrm{H}, \mathrm{s}, \mathrm{CH}_{3}\right) ;$ $2.34\left(3 \mathrm{H}, \mathrm{s}, \mathrm{CH}_{3}\right) ; 7.05\left(2 \mathrm{H}, \mathrm{d}, J=8.4 \mathrm{~Hz}, \mathrm{ArH}_{3}{ }^{\prime}\right.$ and $\left.\mathrm{ArH}_{5}{ }^{\prime}\right) ; 7.42(1 \mathrm{H}$, $\left.\mathrm{t}, J=8.4 \mathrm{~Hz}, \mathrm{ArH}_{4}\right) ; 7.60\left(2 \mathrm{H}, \mathrm{t}, J=5.4 \mathrm{~Hz}, \mathrm{ArH}_{3}\right.$ and $\left.\mathrm{ArH}_{5}\right) ; 8.03(2 \mathrm{H}, \mathrm{d}$, $J=7.5 \mathrm{~Hz}, \mathrm{ArH}_{2}$ and $\left.\mathrm{ArH}_{6}\right) ; 8.11\left(2 \mathrm{H}, \mathrm{d}, J=8.7 \mathrm{~Hz}, \mathrm{ArH}_{2}{ }^{\prime}\right.$ and $\left.\mathrm{ArH}_{6}{ }^{\prime}\right) ; 8.49$ $\left(1 \mathrm{H}, \mathrm{s}, \mathrm{H}_{5}\right) ; 8.74\left(1 \mathrm{H}, \mathrm{s}, \mathrm{H}_{3}\right) . \mathrm{RMN}^{13} \mathrm{C}\left(\delta \mathrm{ppm}, \mathrm{DMSO}-\mathrm{d}_{6}\right): 14.36\left(\mathrm{CH}_{3}\right)$; $22.70\left(\mathrm{CH}_{3}\right) ; 108.83(\mathrm{C}-3 \mathrm{a}) ; 120.12(\mathrm{C}-5) ; 121.32\left(\mathrm{C}-3^{\prime}\right.$ and $\left.\mathrm{C}-5^{3}\right)$, 122.68 (C-6), 126.46 (C-4'), 127.25 (C-2" and C-6"), 129.26 (C-3" and C-5”), 129.83 (C-2' and C-6'), 130.91 (C-1"), 134.15 (C-3), 138.94 (C4"), 139.50 (C-1'), 145.12 (C-4a), 149.67 (C-9a), 163.22 (C-8); HRMS Calculated for $\mathrm{C}_{21} \mathrm{H}_{17} \mathrm{~N}_{5}: 339.1484$, found: 339.1452 .

g) 6-(4-Chlorophenyl)-

$N^{1}$-phenyl-1,7dihydropyrazolo[3,4-d $]$ imidazo $[1,2-f]$ pyrimidine $5 \mathrm{~g}$ : Yield $79 \%$; $\mathrm{mp}$ $168{ }^{\circ} \mathrm{C}$; IR $\left(\mathrm{cm}^{-1}\right): v_{\mathrm{C}=\mathrm{N}} 1501,1556,1595 ; \mathrm{RMN}^{1} \mathrm{H}\left(\delta \mathrm{ppm}, \mathrm{DMSO}-\mathrm{d}_{6}\right)$ : $7.45\left(1 \mathrm{H}, \mathrm{t}, J=7.3 \mathrm{~Hz}, \mathrm{ArH}_{4}\right) ; 7.54\left(2 \mathrm{H}, \mathrm{d}, J=8.4 \mathrm{~Hz}, \mathrm{ArH}_{3}{ }^{\prime}\right.$ and $\left.\mathrm{ArH}_{5}{ }^{\prime}\right)$; $7.62\left(2 \mathrm{H}, \mathrm{t}, J=8.1 \mathrm{~Hz}, \mathrm{ArH}_{3}\right.$ and $\left.\mathrm{ArH}_{5}\right) ; 8.05\left(2 \mathrm{H}, \mathrm{d}, J=8.4 \mathrm{~Hz}, \mathrm{ArH}_{2}\right.$ and $\left.\mathrm{ArH}_{6}\right) ; 8.14\left(2 \mathrm{H}, \mathrm{d}, J=7.8 \mathrm{~Hz}, \mathrm{ArH}_{2}{ }^{\prime}\right.$ and $\left.\mathrm{ArH}_{6}{ }^{\prime}\right) ; 8.58\left(1 \mathrm{H}, \mathrm{s}, \mathrm{H}_{5}\right)$; $8.66\left(1 \mathrm{H}, \mathrm{s}, \mathrm{H}_{3}\right) ; 9.35\left(1 \mathrm{H}, \mathrm{s}, \mathrm{H}_{8}\right) . \mathrm{RMN}^{13} \mathrm{C}\left(\delta \mathrm{ppm}, \mathrm{DMSO}-\mathrm{d}_{6}\right): 108.66$ (C-3a); 120.25 (C-5); 121.77 (C-3' and C-5'), 122.68 (C-6), 127.12 (C4'), 127.40 (C-2" and C-6"), 128.85 (C-3" and C-5"), 129.27 (C-2' and C-6'), 131.83 (C-1"), 132.55 (C-4"), 138.37 (C-3), 139.83 (C-1'), 140.08 (C-8), 142.98 (C-4a), 144.46 (C-9a); HRMS Calculated for $\mathrm{C}_{19} \mathrm{H}_{12} \mathrm{ClN}_{5}$ : 345.0781, found: 345.0789 .

h) 6- (4-Chlorophenyl)-3-methyl- $N^{1}$ - phenyl-1,7dihydropyrazolo[3,4-d]imidazo[1,2-f]pyrimidine 5 h: Yield $69 \%$; mp $192{ }^{\circ} \mathrm{C}$; IR $\left(\mathrm{cm}^{-1}\right): v_{\mathrm{C}=\mathrm{N}} 1504,1561,1591$; $\mathrm{RMN}^{1} \mathrm{H}\left(\delta \mathrm{ppm}, \mathrm{DMSO}-\mathrm{d}_{6}\right)$ : $2.18\left(3 \mathrm{H}, \mathrm{s}, \mathrm{CH}_{3}\right) ; 7.30\left(1 \mathrm{H}, \mathrm{t}, J=7.5 \mathrm{~Hz}, \mathrm{ArH}_{4}\right) ; 7.44(2 \mathrm{H}, \mathrm{d}, J=7.5 \mathrm{~Hz}$, $\mathrm{ArH}_{3}{ }^{\prime}$ and $\left.\mathrm{ArH}_{5}{ }^{\prime}\right) ; 7.59\left(2 \mathrm{H}, \mathrm{t}, J=7.8 \mathrm{~Hz}, \mathrm{ArH}_{3}\right.$ and $\left.\mathrm{ArH}_{5}\right) ; 7.67(2 \mathrm{H}, \mathrm{d}$, $J=7.3 \mathrm{~Hz}, \mathrm{ArH}_{2}$ and $\left.\mathrm{ArH}_{6}\right) ; 7.79\left(2 \mathrm{H}, \mathrm{d}, J=7.5 \mathrm{~Hz}, \mathrm{ArH}_{2}{ }^{\prime}\right.$ and $\left.\mathrm{ArH}_{6}{ }^{\prime}\right) ; 8.48$ $\left(1 \mathrm{H}, \mathrm{s}, \mathrm{H}_{5}\right)$; $9.21\left(1 \mathrm{H}, \mathrm{s}, \mathrm{H}_{8}\right) . \mathrm{RMN}^{13} \mathrm{C}\left(\delta \mathrm{ppm}, \mathrm{DMSO}-\mathrm{d}_{6}\right): 14.42\left(\mathrm{CH}_{3}\right)$; 108.29 (C-3a); 120.74 (C-5); 121.32 (C-3' and C-5'), 122.64 (C-6), 127.19 (C-4'), 127.51 (C-2" and C-6"), 128.87 (C-3" and C-5"), 129.12 (C-2' and C-6'), 132.11 (C-1"), 132.83 (C-4"), 135.61 (C-3), 139.83 (C1'), 143.59 (C-4a), 146.28 (C-9a), 162.31 (C-8); HRMS Calculated for $\mathrm{C}_{20} \mathrm{H}_{14} \mathrm{ClN}_{5}: 359.0938$, found: 359.0923 .

i) 6- (4-Chlorophenyl)-8-methyl- $N^{1}$ - phenyl-1,7dihydropyrazolo $[3,4-d]$ imidazo $[1,2-f]$ pyrimidine 5 i: Yield $67 \%$; mp $189^{\circ} \mathrm{C}$; IR $\left(\mathrm{cm}^{-1}\right): v_{\mathrm{C}=\mathrm{N}} 1511,1553,1594$; $\mathrm{RMN}^{1} \mathrm{H}\left(\delta \mathrm{ppm}, \mathrm{DMSO}-\mathrm{d}_{6}\right)$ : $2.24\left(3 \mathrm{H}, \mathrm{s}, \mathrm{CH}_{3}\right) ; 7.18\left(1 \mathrm{H}, \mathrm{t}, J=7.0 \mathrm{~Hz}, \mathrm{ArH}_{4}\right) ; 7.35(2 \mathrm{H}, \mathrm{d}, J=7.5 \mathrm{~Hz}$, $\mathrm{ArH}_{3}{ }^{\prime}$ and $\left.\mathrm{ArH}_{5}{ }^{\prime}\right) ; 7.54\left(2 \mathrm{H}, \mathrm{t}, J=8.0 \mathrm{~Hz}, \mathrm{ArH}_{3}\right.$ and $\left.\mathrm{ArH}_{5}\right) ; 7.68(2 \mathrm{H}, \mathrm{d}$, $J=7.5 \mathrm{~Hz}, \mathrm{ArH}_{2}$ and $\left.\mathrm{ArH}_{6}\right) ; 7.74\left(2 \mathrm{H}, \mathrm{d}, J=7.5 \mathrm{~Hz}, \mathrm{ArH}_{2}{ }^{\prime}\right.$ and $\left.\mathrm{ArH}_{6}{ }^{\prime}\right) ; 8.51$ $\left(1 \mathrm{H}, \mathrm{s}, \mathrm{H}_{5}\right) ; 8.82\left(1 \mathrm{H}, \mathrm{s}, \mathrm{H}_{3}\right) . \mathrm{RMN}^{13} \mathrm{C}\left(\delta \mathrm{ppm}, \mathrm{DMSO}-\mathrm{d}_{6}\right): 14.64\left(\mathrm{CH}_{3}\right)$; 108.43 (C-3a); 120.68 (C-5); 121.36 (C-3' and C-5'), 122.85 (C-6), 127.07 (C-4'), 127.23 (C-2" and C-6"), 128.69 (C-3" and C-5"), 129.81 (C-2' and C-6'), 131.54 (C-1"), 132.76 (C-4"), 139.84 (C-1'), 141.22 (C8), 143.36 (C-4a), 143.76 (C-3), 145.84 (C-9a); HRMS Calculated for $\mathrm{C}_{20} \mathrm{H}_{14} \mathrm{ClN}_{5}: 359.0938$, found: 359.0941 .

\section{Pharmacology}

Chemicals and drugs: Carrageenan (BDH Chemicals Ltd., Poole, England), ranitidine (Medis, Tunis, Tunisia) and diclofenac (Medis, Tunis, Tunisia) were purchased from Central pharmacy of Tunisia.

Animals: Westar rats of either sex, weighing 150-180 g of both sexes were obtained from Pasteur Institute (Tunis, Tunisia). Housing conditions and in vivo experiments were approved according to the guidelines established by the European Union on Animal Care (CCE Council 86/609).

\section{Antioxidant activities:}

DPPH radical-scavenging activity: The free radical-scavenging activity of compounds ( $5 \mathrm{a}, \mathrm{b}, \mathrm{c}, \mathrm{d}$ ) were evaluated using the stable radical DPPH, according to the method of Kim et al. [7]. One milliliter of diluted sample $(1 \mathrm{mg} / \mathrm{mL})$ was added to $1 \mathrm{~mL}$ of the ethanolic DPPH solution. The mixture was then shaken and allowed to stand at room temperature in the dark. After $30 \mathrm{~min}$, the decrease in absorbance at $517 \mathrm{~nm}$ was measured against a blank (ethanol solution) by using a UVVis spectrophotometer. A mixture consisting of $1 \mathrm{~mL}$ of ethanol and 1 $\mathrm{mL}$ of DPPH solution was used as the control. The radical-scavenging activity of test samples, expressed as percentage inhibition of DPPH, was calculated according to the formula:

$\%$ inhibition $=\left[\left(A_{B}-A_{A}\right) / A_{B}\right] \times 100$, where $A_{B}$ and $A_{A}$ are the absorbance values of the control and of the test sample, respectively. The compound concentration providing $50 \%$ inhibition $\left(\mathrm{IC}_{50}\right)$ was calculated from the graph of inhibition percentage plotted against 
test samples concentration. DPPH radical-scavenging activity of compounds (5a, b, c, d) were compared with ascorbic acid used as standard.

Ferric reducing antioxidant power (FRAP): The ferric reducing power (FRAP) of compounds (5a, b, c, d) was evaluated using the method described by Zaouali et al. [8]. Briefly, one milliliter of diluted sample $(1 \mathrm{mg} / \mathrm{mL})$ was mixed with $2.5 \mathrm{~mL}$ of Potassium phosphate buffer (0.1 M, pH 6.6) and $2.5 \mathrm{~mL}$ of $1 \%(\mathrm{w} / \mathrm{v})$ potassium ferricyanide. The mixture was incubated at $50{ }^{\circ} \mathrm{C}$ for $20 \mathrm{~min}$, thereafter $2.5 \mathrm{~mL}$ of $10 \%(\mathrm{w} / \mathrm{v})$ trichloroacetic acid was added, and subsequently centrifuged at $1000 \times \mathrm{g}$ for $10 \mathrm{~min} .2 .5 \mathrm{~mL}$ of the supernatant was mixed with equal volume of water and $0.5 \mathrm{~mL}$ of $0.1 \%(\mathrm{w} / \mathrm{v})$ ferric chloride. The solution was incubated at ambient temperature for $30 \mathrm{~min}$ for color development. The absorbance of all sample solutions was measured at $700 \mathrm{~nm}$ and compared with ascorbic acid used as standard.

Carrageenan-induced rat paw oedema: Wistar rats were divided into groups of six animals. Oedema was induced by injecting $0.05 \mathrm{~mL}$ of $1 \%$ carrageenan subcutaneously into the sub-plantar region of the left hind paw. Compounds 5a, b, c and d (50 and $100 \mathrm{mg} / \mathrm{kg}$ ) were administered intraperitoneally (i.p.). The control group received the vehicle (Tween $80 /$ absolute ethanol/saline solution ( $0.9 \%$ ) in the ratio 1:1:18) (2.5 mL/ kg, i.p.). The reference group received dichlofenac (25 $\mathrm{mg} / \mathrm{kg}$, i.p). All drugs were administrated $30 \mathrm{~min}$ before the injection of carrageenan. Measurement of paw size was done by means of volume displacement technique using plethysmometer (Ugo Basile no.7140) immediately before carrageenan injection and $1,2,3,4$ and $5 \mathrm{~h}$ after carrageenan injection. Percentages of inhibition in our antiinflammatory tests were obtained for each group using the following ratio: $\left[\left(\mathrm{V}_{\mathrm{t}}-\mathrm{V}_{\mathrm{o}}\right)\right.$ control $-\left(\mathrm{V}_{\mathrm{t}}-\mathrm{V}_{\mathrm{o}}\right)$ treated $] \times 100 /\left(\mathrm{V}_{\mathrm{t}}-\mathrm{V}_{\mathrm{o}}\right)$ Control

Where, $V_{t}$ is the average volume for each group and $V_{o}$ is the average volume obtained for each group before any treatment.

Gastroprotective activity: Westar rats were initially treated with compounds 5a, b, c, d (50 and $100 \mathrm{mg} / \mathrm{kg}$, i.p.). After $30 \mathrm{~min}$, gastric damage was induced in the experimental groups by $150 \mathrm{mM} \mathrm{HCl} / \mathrm{EtOH}$ $(40: 60, \mathrm{v} / \mathrm{v})$ orally administration $(1 \mathrm{~mL} / 100 \mathrm{~g})$, while the control group received vehicle and the reference group received ranitidine $(60 \mathrm{mg} /$ $\mathrm{kg}$, i.p). One hour later, the animals were sacrificed and their stomachs rapidly removed and opened via an incision along the greater curvature [9]. Gastric damage was determined by measuring the extent of the ulcerative lesions. The summative length of these lesions was recorded $(\mathrm{mm})$ as lesion index.

Acetic acid writhing test in mice: The analgesic activity was performed according to the method of Ayed et al. [10]. Swiss mice $(20-30 \mathrm{~g})$ were selected one day prior to each test and were divided into six groups of six mice each. One group served as control (vehicle $10 \mathrm{ml} / \mathrm{kg}$ ) by subcutaneous injection $(\mathrm{s} / \mathrm{c})$. The second group was given the acetylsalicylate of lysine (ASL) $(200 \mathrm{mg} / \mathrm{kg})$ by the same route, as a reference drug. The remaining group was treated with compounds $5 \mathrm{a}, \mathrm{b}, \mathrm{c}, \mathrm{d}(50$ and $100 \mathrm{mg} / \mathrm{kg},(\mathrm{s} / \mathrm{c}))$. All animals received $10 \mathrm{ml} / \mathrm{kg}$ (i.p.) of $1 \%$ acetic acid $30 \mathrm{~min}$ after treatment. The number of writhing was recorded during $30 \mathrm{~min}$ commencing $5 \mathrm{~min}$ after the acetic acid injection. A writhe is indicated by abdominal constriction and stretching of at least one hind limb.

Anticandidal activity: The antifungal effect of compounds $5 \mathrm{a}, \mathrm{b}$, c, d was tested against three Candida strains (Candida albicans ATCC 90028, Candida glabrata ATCC 90030 and Candida parapsilosis ATCC 22019). The minimal inhibitory concentration (MIC) preventing visible fungal growth was measured by the broth dilution method (microdilution using 96-well microplates), following the procedure of
Hammer et al. [11]. Compounds 5a, b, c, d solutions were prepared by dissolution in $10 \%$ dimethyl sulfoxide (DMSO). The compounds concentrations tested ranged from 0.1 to $10 \mathrm{mg} / \mathrm{ml}$. The MIC of each compound was defined as the lowest concentration which inhibited candidal growth after incubation at $37^{\circ} \mathrm{C}$ between 18 and $24 \mathrm{~h}$. The minimal fungicidal concentration (MFC) was determined by subculture on blood agar at $37^{\circ} \mathrm{C}$ between 18 and $24 \mathrm{~h}$. Amphotericin B was used as anticandidal positive control.

\section{Statistical analysis}

Data are presented as the mean \pm standard error of the mean (s.e.m). Statistical analysis was performed using Student's $t$-test. The significance of difference was considered to include values of $P<0.05$.

\section{Results and Discussion}

\section{Chemistry}

The 5-amino-4-cyano- $N^{1}$-phenylpyrazole 2, used as a starting material, was prepared in two steps following a similar method reported by Petrie and al [12-14]. The first step involves acid catalyzed condensation of orthoester with malonate to form ethoxymethylene malononitrile 1 . This later reacts then with substituted hydrazine to give the aminocyanopyrazole 2 . Treatment of 2 with orthoester in the presence of catalytic amount of acid furnished the corresponding cyano-pyrazoloimidates 3 which subsequently were transformed to the corresponding amino pyrazolopyrimidines 4 upon treatment with ammoniac [5,15-17]. Reaction of compound 4 with a-bromoacetophenone in the presence of a catalytic amount of PTSA (5 mol\%) in refluxing ethanol furnished the 1,7-dihydropyrazolo[3,4- $d]$ imidazo[1,2-f]pyrimidines derivatives 5. 1,7-dihydropyrazolo[3,4- $d]$ imidazo[1,2-f]pyrimidines derivatives 5 were isolated as stable compounds in good yields.

The reaction occurs by a primary amino group intercepts a bromine atom liberating $\mathrm{HBr}$, followed by an intracyclisation and elimination of a water molecule to give 1,7-dihydropyrazolo[3,4- $d$ ]imidazo[1,2- $f$ ] pyrimidines $5 \mathrm{a}-\mathrm{i}$. It is interesting to note that time reaction and yield of products are directly related to the nature of substituent $\left(\mathrm{R}_{1}, \mathrm{R}_{2}\right.$ and $\left.\mathrm{R}_{3}\right)$. The yields of compounds $5 \mathrm{a}$ and $5 \mathrm{c}$ are 74 and $81 \%$, respectively. When $\mathrm{R}$ is a hydrogen substituent, the product is obtained with superior yield in short time (e.g., Compounds $5 b$ and $5 c$ and 5 g.). From these results, we conclude that the electronic nature of the substituent on the bromoacetophenone has a significant role on the reaction outcome. The correct identity of compound as 1,7-dihydropyrazolo[3,4- $d$ ] imidazo[1,2-f]pyrimidines was confirmed by ${ }^{1} \mathrm{H}$ NMR, ${ }^{13} \mathrm{C}$ NMR and HRMS (Scheme 1; Table 1).

\section{Pharmacology}

Antioxidant activities: Free radicals have an important role in pathogenesis of a wide range of diseases including inflammation. Antioxidants can prevent biological and chemical substances from free radical induced oxidative damage and stress. Consequently, multipotent antioxidants have gained a great attention from scientists for their potential in treatment of many diseases [18]. In this study, two methods were used to evaluate the antioxidant activity of compounds $5 \mathrm{a}, \mathrm{b}, \mathrm{c}, \mathrm{d}$; the DPPH radical-scavenging activity and ferric reducing antioxidant power (FRAP). Figure 1 show that the radical-scavenging activity of compounds (5a, b, c, d) and ascorbic acid on DPPH radicals increased in dose-dependent manner. The $\mathrm{IC}_{50}$ values calculated from the graph (Figure 1) show that compound 5a exhibited significant antioxidant activity with $\mathrm{IC}_{50}$ values of $0.037 \mathrm{mg} / \mathrm{mL}$, whereas, compound $5 \mathrm{~b}$ exhibited moderate activity $\left(\mathrm{IC}_{50}\right.$ value of $\left.0.049 \mathrm{mg} / \mathrm{mL}\right)$. Compounds 


\begin{tabular}{|c|c|c|c|c|c|c|}
\hline Compounds & $\mathbf{R}_{\mathbf{1}}$ & $\mathbf{R}_{\mathbf{2}}$ & $\mathbf{R}_{\mathbf{3}}$ & Yields (\%) & $\mathbf{M p}\left({ }^{\circ} \mathbf{C}\right)$ & Reaction time (h) \\
\hline$\underline{\mathbf{5 a}}$ & $\mathrm{CH}_{3}$ & $\mathrm{H}$ & $4-\mathrm{OCH}_{3}$ & 74 & 210 & 12 \\
\hline$\underline{\mathbf{5 b}}$ & $\mathrm{H}$ & $\mathrm{H}$ & $4-\mathrm{OCH}_{3}$ & 78 & 171 & 7 \\
\hline$\underline{\mathbf{5 c}}$ & $\mathrm{H}$ & $\mathrm{H}$ & $4-\mathrm{CH}_{3}$ & 81 & 166 & 5 \\
\hline$\underline{\mathbf{5 d}}$ & $\mathrm{CH}_{3}$ & $\mathrm{H}$ & $4-\mathrm{CH}_{3}$ & 69 & 206 & 12 \\
\hline$\underline{\mathbf{5}}$ & $\mathrm{H}$ & $\mathrm{CH}_{3}$ & $4-\mathrm{OCH}_{3}$ & 62 & 212 & 24 \\
\hline$\underline{\mathbf{5 f}}$ & $\mathrm{H}$ & $\mathrm{CH}_{3}$ & $4-\mathrm{CH}_{3}$ & 58 & 205 & 18 \\
\hline$\underline{\mathbf{5 g}}$ & $\mathrm{H}$ & $\mathrm{H}$ & $4-\mathrm{Cl}$ & 79 & 168 & 5 \\
\hline$\underline{\mathbf{5 h}}$ & $\mathrm{CH}_{3}$ & $\mathrm{H}$ & $4-\mathrm{Cl}$ & 69 & 192 & 10 \\
\hline$\underline{\mathbf{5 i}}$ & $\mathrm{H}$ & $\mathrm{CH}_{3}$ & $4-\mathrm{Cl}$ & 67 & 189 & 17 \\
\hline
\end{tabular}

Table 1: Synthesis of 1,7-dihydropyrazolo[3,4-d]imidazo[1,2-f]pyrimidines 5a-i.

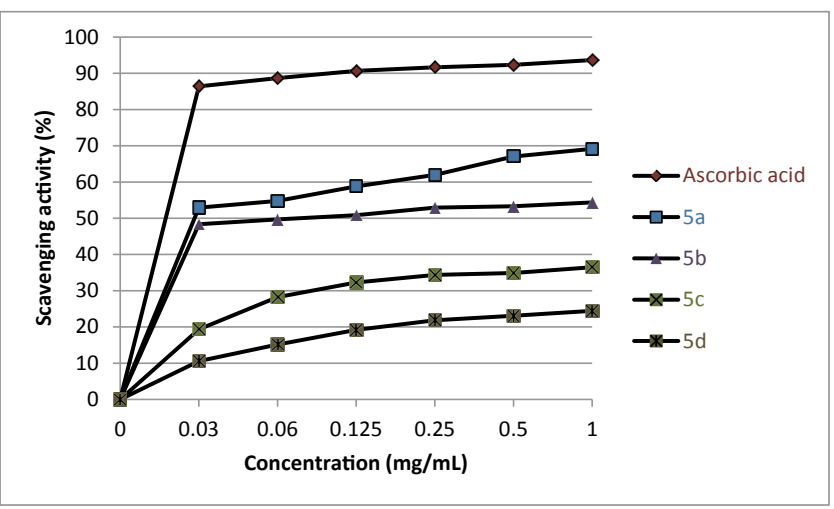

Figure 1: Free radical-scavenging activity of compounds $\mathbf{5 a}, \mathbf{5 b}, \mathbf{5 c}$ and $\mathbf{5 d}$ and ascorbic acid on DPPH.

$5 \mathrm{c}$, d don't have any activity. So, compound $5 \mathrm{a}, \mathrm{b}$ have the highest free radical scavenging activity, which was found to be comparable with that of ascorbic acid $\left(\mathrm{IC}_{50}=0.013 \mathrm{mg} / \mathrm{mL}\right)$ (Table 2$)$.

In addition, Figure 2 shows the ability of compounds $(5 \mathrm{a}, \mathrm{b}, \mathrm{c}$, d) and ascorbic acid to reduce $\mathrm{Fe}^{3+}$ to $\mathrm{Fe}^{2+}$ at different concentration ranges. The reducing potential of compounds (5a, b, c, d) and ascorbic acid increased with increase of concentrations. Compound $5 \mathrm{a}$ had the highest reducing power, with $\mathrm{IC}_{50}=0.042 \mathrm{mg} / \mathrm{mL}$ followed by compound $5 \mathrm{~b}\left(\mathrm{IC}_{50}=0.065 \mathrm{mg} / \mathrm{mL}\right.$ ) (Table 2). The FRAP values of compounds $5 \mathrm{a}, \mathrm{b}$ were comparable with that of ascorbic acid $\left(\mathrm{IC}_{50}=\right.$ $0.025 \mathrm{mg} / \mathrm{mL}$ ), however compounds $5 \mathrm{c}$, d showed a lower reducing power (Table 2). These different values of $\mathrm{IC}_{50}$ indicated that the order of increasing reductive potential of ferric iron was $5 b<5 a<$ ascorbic acid.

The reducing power of various compounds might be due to their hydrogen-donating ability as described by Shimada et al. [19]. So, compounds $5 \mathrm{a}, \mathrm{b}$ is good electron donors and could terminate the free-radical chain reactions by converting free radicals to more stable products (Figure 2).

Anti-inflammatory activity: The anti-inflammatory activity of compounds $5 \mathrm{a}, \mathrm{b}, \mathrm{c}, \mathrm{d}$ against acute pedal edema (induced by carrageenan) is shown in Table 3 and the results are comparable to that of the standard drug diclofenac, a potent inhibitor of cyclooxygenase 2 (Cox-2). Carrageenan induced paw edema remained even $6 \mathrm{~h}$ after its injection into the sub plantar region of rat paw. Diclofenac as a reference standard drug inhibited the edema formation due to carrageenan to an extent of $58.22 \%$ (at $3 \mathrm{~h}$ ) at the dose of $25 \mathrm{mg} / \mathrm{kg}$. The compounds $5 \mathrm{a}, \mathrm{b}, \mathrm{c}, \mathrm{d}$ inhibited, significantly edema formation in rats $(\mathrm{p}<0.01)$ in a dose dependent manner. Compound $5 \mathrm{a}$ at the dose of $50 \mathrm{mg} / \mathrm{kg}$ inhibited edema formation to the extent of $74.5 \%$ (at $3 \mathrm{~h}$ ) and the edema was found to be reduced to $5.25 \pm 210^{-2} \mathrm{~mL}$ (Figure 3). The compound $5 \mathrm{~b}$ has also a height activity at a dose of $50 \mathrm{mg} /$

\begin{tabular}{|c|c|c|}
\hline Sample & $\begin{array}{c}\text { IC }_{\mathbf{5 0}}{ }^{\text {a }} \text { of DPPH radical- } \\
\text { scavenging activity }(\mathbf{m g} / \mathbf{m l})\end{array}$ & IC $_{\mathbf{5 0}}{ }^{\mathrm{b}}$ of reducing power $(\mathbf{m g} / \mathrm{ml})$ \\
\hline $\mathbf{5 a}$ & $0.037 \pm 0.01$ & $0.042 \pm 0.02$ \\
\hline $\mathbf{5 b}$ & $0.049 \pm 0.03$ & $0.065 \pm 0.03$ \\
\hline $\mathbf{5 c}$ & - & - \\
\hline $\mathbf{5 d}$ & - & - \\
\hline $\begin{array}{c}\text { Ascorbic } \\
\text { acid }\end{array}$ & $0.013 \pm 0.02$ & $0.025 \pm 0.01$ \\
\hline
\end{tabular}

Values are expressed as mean \pm SEM of triplicate measurement. ${ }^{a} C_{50}$ means the concentration of sample that can decrease DPPH concentration by $50 \%$.

${ }^{\mathrm{b}} \mathrm{C}_{50}$ is the concentration for which the absorbance at $700 \mathrm{~nm}$ is 0.5 .

Table 2: $I_{50}$ values of DPPH radical-scavenging activity and reducing power of compound $\mathbf{5 a}, \mathbf{5 b}, \mathbf{5 c}$ and $\mathbf{5 d}$.

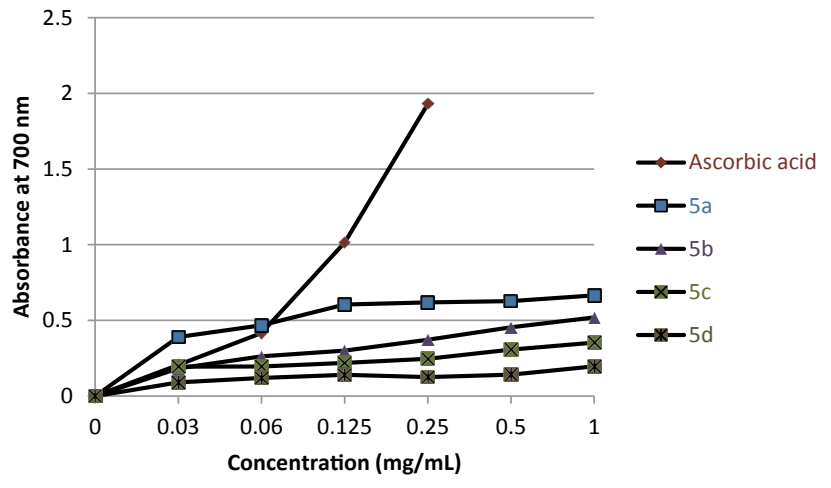

Figure 2: Reductive potential of compounds $\mathbf{5 a}, \mathbf{5 b}, \mathbf{5 c}$ and $\mathbf{5 d}$ and ascorbic acid using spectrophotometric detection of $\mathrm{Fe}^{3+}-\mathrm{Fe}^{2+}$ transformations.

$\mathrm{kg}$ with a percentage of inhibition of edema of $65.54 \%$ (at $3 \mathrm{~h}$ ), while compounds $5 \mathrm{c}$ and $5 \mathrm{~d}$ at a dose of $50 \mathrm{mg} / \mathrm{kg}$ reduced edema with a percentage of 48.66 and $44.21 \%$, respectively. The presence of edema is one of the prime signs of inflammation [20]. It has been documented that carrageenan induced rat paw edema is suitable in vivo model to study anti-inflammatory drugs both steroidal and non-steroidal since it involves several mediators [21]. This method was chosen for the present study since edema induced by carrageenan is the most prominent acute experimental model in search for new anti-inflammatory drugs [20]. Carrageenan induced edema has been commonly used as an experimental animal model for acute inflammation and is believed to be biphasic [22]. The early phase (1-2 h) of the carrageenan model is mainly mediated by histamine, serotonin and increased synthesis of prostaglandins in the damaged tissue surroundings. The late phase (2.5$5 \mathrm{~h}$ ) is due to the over production of prostaglandin and nitric oxide with peak at $5 \mathrm{~h}$, produced by inducible isoforms of cox (cox-2) and nitric oxide synthase (iNOS) [23].

However, treatment with compounds $5 \mathrm{a}, \mathrm{b}, \mathrm{c}$, d significantly reduced carrageenan on induced inflammation in both the phases (1-5 h) of the experiment. Based on this, it may be that compounds $5 \mathrm{a}, \mathrm{b}, \mathrm{c}$, $d$ have a non-selective inhibiting effect on the release or actions of these mediators of inflammation and the suppression of the $1^{\text {st }}$ phase may be due to inhibition of the release of early mediators, such as histamine and serotonin and the action in the $2^{\text {nd }}$ phase may be explained by an inhibition of cyclooxygenase 2 .

Gastroprotective activity: The results of gastroprotective activity of compounds $5 \mathrm{a}, \mathrm{b}, \mathrm{c}, \mathrm{d}$ on gastric ulcer induced by $\mathrm{HCl} /$ ethanol solution are shown in Table 4. Oral administration of the damaging agent to the control group clearly produced a mucosal damage characterized by 


\begin{tabular}{|c|c|c|c|c|c|c|c|}
\hline \multirow[t]{2}{*}{ Treatment } & \multirow[t]{2}{*}{ Dose (mg/kg) } & \multicolumn{3}{|c|}{ Edema $\left(10^{-2} \mathrm{~mL}\right)($ mean \pm S.E.M) } & \multicolumn{3}{|c|}{ Edema inhibition (\%) } \\
\hline & & $1 \mathrm{~h}$ & $3 \mathrm{~h}$ & $5 \mathrm{~h}$ & $1 \mathrm{~h}$ & $3 \mathrm{~h}$ & $5 \mathrm{~h}$ \\
\hline Vehicle & - & $25.5 \pm 2.3$ & $37.5 \pm 2.2$ & $42.6 \pm 2.6$ & - & - & - \\
\hline Diclofenac & 25 & $13.22 \pm 2.7^{*}$ & $15.67 \pm 2.1^{*}$ & $20.05 \pm 2.9^{*}$ & 48.15 & 58.22 & 52.94 \\
\hline \multirow[t]{2}{*}{$5 a$} & 50 & $7.62 \pm 1.4^{* *}$ & $9.56 \pm 1.6^{* \star}$ & $12.63 \pm 2.2^{* \star}$ & 70.11 & 74.5 & 70.35 \\
\hline & 100 & $3.75 \pm 1.6^{\star *}$ & $5.25 \pm 2^{* *}$ & $7.75 \pm 2.2^{\star \star}$ & 85.29 & 86 & 81.8 \\
\hline \multirow[t]{2}{*}{$5 b$} & 50 & $10.6 \pm 2.2^{*}$ & $12.92 \pm 2.3^{* *}$ & $15.19 \pm 1.8^{* *}$ & 58.43 & 65.54 & 64.34 \\
\hline & 100 & $6.75 \pm 2.2^{\star *}$ & $8.75 \pm 1.8^{* \star}$ & $10.25 \pm 2.3^{* \star}$ & 73.52 & 76.66 & 75.93 \\
\hline \multirow[t]{2}{*}{$5 c$} & 50 & $13.17 \pm 2.4^{*}$ & $19.25 \pm 1.6^{*}$ & $22.78 \pm 2.4^{*}$ & 48.35 & 48.66 & 46.52 \\
\hline & 100 & $9 \pm 2.3^{* *}$ & $13 \pm 2.3^{* *}$ & $16.25 \pm 1.6^{* \star}$ & 64.7 & 65.33 & 61.85 \\
\hline \multirow[t]{2}{*}{$5 d$} & 50 & $14.58 \pm 1.8$ & $20.92 \pm 2.2^{*}$ & $25.3 \pm 2.4$ & 42.82 & 44.21 & 40.61 \\
\hline & 100 & $8 \pm 2.3^{* *}$ & $11.75 \pm 1.8^{\star *}$ & $14.2 \pm 1.6^{\star \star}$ & 68.62 & 68.66 & 66.66 \\
\hline
\end{tabular}

Values are expressed as mean \pm SEM; $n=6$ animals. ${ }^{*} \mathrm{P}<0.01,{ }^{*} \mathrm{P}<0.001$

Vehicle: Ethanol: 5\%; Tween 80: $5 \%$; distilled water: $90 \%$

Table 3: Anti-inflammatory effect of the intraperitoneal administration of compounds $\mathbf{5 a}, \mathbf{5 b}, \mathbf{5} \mathbf{c}$ and $\mathbf{5 d}$ and of reference drug (Diclofenac) in carrageenan-induced rat paw edema test.

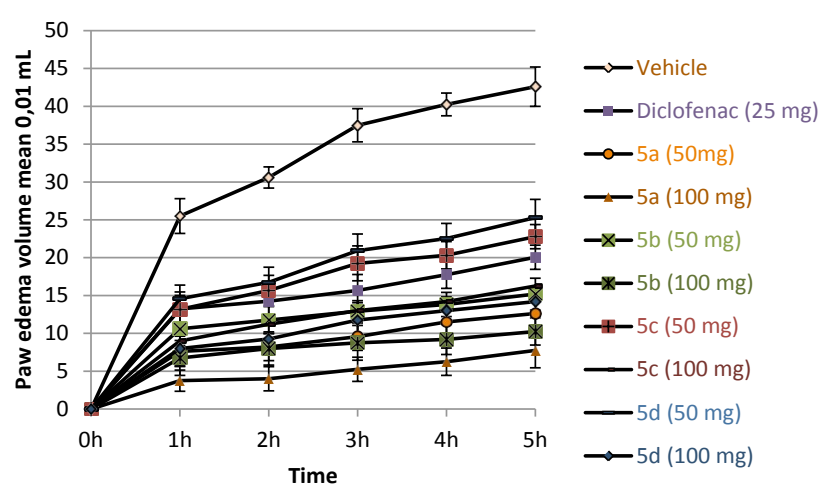

Figure 3: Effect of intraperitoneal administration of compounds $\mathbf{5 a}, \mathbf{b}, \mathbf{c}, \mathbf{d}$ on the carrageenan-induced rat paw edema. Values are mean \pm SEM.

multiple haemorrhage red bands of different sizes along the long axis of the glandular stomach [9].

As shown in Table 4, the compound 5a significantly exhibited, at the dose of $100 \mathrm{mg} / \mathrm{kg}$, the higher inhibition of gastric lesions $(76.53 \%)$ than compound $5 \mathrm{~b}$ at the same dose $(65.48 \%)$. The gastroprotective effect of the two compounds $5 \mathrm{a}$ and $5 \mathrm{~b}$ were similar to the effect produced by the reference drug, ranitidine, which exhibited $65.24 \%$ of inhibition. However, $5 \mathrm{c}$ and $5 \mathrm{~d}$ were less effective than the reference drug; the percentage of inhibition of gastric lesions was $46.11 \%$ and $39.36 \%$, respectively, at the dose of $100 \mathrm{mg} / \mathrm{kg}$ (Figure 4). As described by Jonsson et al. ethanol administration resulted in severe mucosal damage through an increase in reactive oxygen species generation and a decrease in the endogenous antioxidant defense mechanisms. So, oxygen-derived free radicals (ROS) may contribute to ethanol induced gastric mucosal lesions [24]. Thus, compounds $5 \mathrm{a}$ and $5 \mathrm{~b}$ may function by decreasing the redox state in $\mathrm{HCl}$ /ethanol induced gastropathy (Figure 4).

Analgesic activity: In addition to the anti-inflammatory activity, the study of analgesic properties of compounds $5 \mathrm{a}, \mathrm{b}, \mathrm{c}$, d were also evaluated. Among the several models of visceral pain, we use the acetic acid writhing test in mice. Acetic acid acts indirectly by inducing the release of endogenous mediator, which stimulates the nociceptive neurons sensitive to NSAIDs (nonsteroidal anti-inflammatory drugs) and/or opioids [25]. Injection of acetic acid into the control mice resulted in 72.44 writhes. Pretreatment with compounds 5a, b, c, d at doses 50 and $100 \mathrm{mg} / \mathrm{kg}$ reduced the number of writhes in a dose dependant manner. Interestingly, compounds $5 \mathrm{a}$ (16.82 writhes, $76.78 \%$

\begin{tabular}{|c|c|c|c|}
\hline Treatment & Dose (mg/kg) & Ulcer index (mm) & Inhibition (\%) \\
\hline Vehicle & - & $65.24 \pm 4.9$ & - \\
\hline \multirow[t]{2}{*}{$5 a$} & 50 & $24.32 \pm 1.6^{* *}$ & 62.72 \\
\hline & 100 & $15.31 \pm 2,8^{* *}$ & 76.53 \\
\hline \multirow[t]{2}{*}{$5 b$} & 50 & $37.68 \pm 1.4^{*}$ & 42.23 \\
\hline & 100 & $22.52 \pm 2.8^{* *}$ & 65.48 \\
\hline \multirow[t]{2}{*}{$5 c$} & 50 & $40.70 \pm 3.2$ & 37.61 \\
\hline & 100 & $35.15 \pm 3.6$ & 46.11 \\
\hline \multirow[t]{2}{*}{$5 d$} & 50 & $50.33 \pm 1.4$ & 22.84 \\
\hline & 100 & $39.56 \pm 1.6$ & 39.36 \\
\hline Ranitidine & 60 & $22.68 \pm 2.9^{* *}$ & 65.23 \\
\hline
\end{tabular}

Values are expressed as mean \pm SEM; $n=6$ animals. ${ }^{*} P<0.01,{ }^{* *} P<0.001$.

Table 4: Effect of compounds $5 a, 5 b, 5 c$ and $5 d$, and of reference drug (ranitidine) on gastric ulcer induced by $\mathrm{HCl} /$ ethanol in rats.

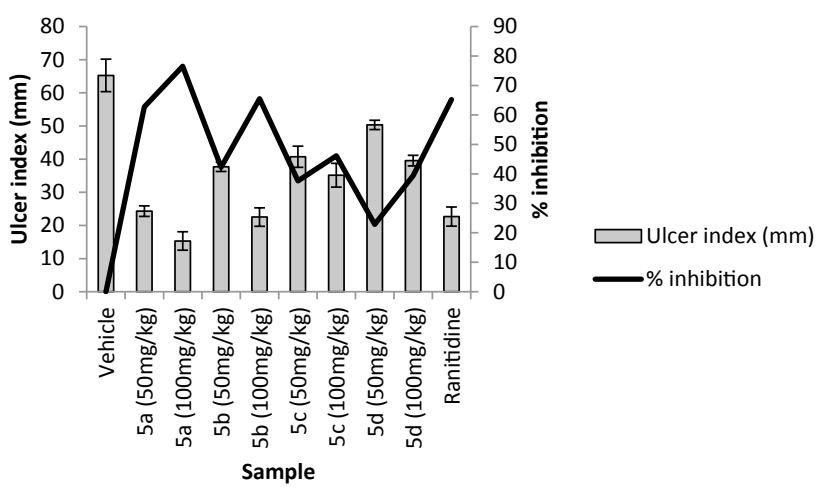

Figure 4: Effect of compounds $5 a, b, c, d$ and the reference drug (Ranitidine) on gastric ulcer induced by $\mathrm{HCl} /$ Ethanol in rats. Data expressed as mean $\pm \mathrm{SEM}$ $(n=6)$. Significantly different from control group: ${ }^{*} p<0.05 ;{ }^{* *} p<0.01 ;{ }^{* * *} p<0.001$.

of inhibition) and $5 \mathrm{~b}$ (20.84 writhes, $71.23 \%$ of inhibition) at a dose of $100 \mathrm{mg} / \mathrm{kg}$ registered higher levels of analgesic activity than $5 \mathrm{c}(39.22$ writhes, $45.85 \%$ of inhibition) and $5 \mathrm{~d}$ (32.56 writhes, $55 \%$ of inhibition) and approaches the activity of the standard drug ASL (20.24 writhes, $72 \%$ of inhibition) (Table 5).

Anticandidal activity: Anticandidal activity is reported as MIC and MFC (Table 6). All compounds showed significant antifungal activity against Candida strains. The best activity was observed with compounds $5 \mathrm{a}, \mathrm{b}$ against Candida albicans. $5 \mathrm{a}$ had the highest anticandidal effect in all yeast strains with MIC ranged from 0.62 to $1.22 \mathrm{mg} / \mathrm{ml}$, followed by $5 b, d$ and $c$ which demonstrated antifungal properties depending from the candidal strains. The MICs ranged from 0.84 to $3.42 \mathrm{mg} / \mathrm{ml}$. 


\begin{tabular}{|c|c|c|c|}
\hline Treatment & Dose $(\mathrm{mg} / \mathrm{kg})$ & Number of writhes \pm SEM & Inhibition of writhing (\%) \\
\hline Vehicle & - & $72.44 \pm 3.5$ & - \\
\hline ASL & 200 & $20.24 \pm 1.6^{* *}$ & 72.06 \\
\hline \multirow[t]{2}{*}{$5 a$} & 50 & $22.52 \pm 2.5^{\star *}$ & 68.91 \\
\hline & 100 & $16.82 \pm 1.4^{\star *}$ & 76.78 \\
\hline \multirow[t]{2}{*}{$5 b$} & 50 & $28.64 \pm 2.8^{*}$ & 60.46 \\
\hline & 100 & $20.84 \pm 3.2^{* *}$ & 71.23 \\
\hline \multirow[t]{2}{*}{$5 c$} & 50 & $46.82 \pm 1.6$ & 35.36 \\
\hline & 100 & $39.22 \pm 2.4$ & 45.85 \\
\hline \multirow[t]{2}{*}{$5 d$} & 50 & $42.14 \pm 3.6$ & 41.82 \\
\hline & 100 & $32.56 \pm 1.4^{*}$ & 55.05 \\
\hline
\end{tabular}

Values are expressed as mean $\pm \mathrm{SEM} ; \mathrm{n}=6$ animals. ${ }^{*} \mathrm{P}<0.01,{ }^{*} \mathrm{P}<0.001$

Vehicle: Ethanol: 5\%; Tween 80: 5\%; distilled water: $90 \%$

Table 5: Analgesic effect of the subcutaneous administration of compounds $\mathbf{5 a}, \mathbf{5 b}, \mathbf{5} \mathbf{c}$ and $\mathbf{5 d}$ and of reference drug lysine acetylsalicylate (ASL) in the acetic acid $1 \%$ writhing test in mice.

\begin{tabular}{|l|c|c|c|c|c|c|}
\hline & \multicolumn{2}{|c|}{ C. albicans ATCC $\mathbf{9 0 0 2 8}$} & \multicolumn{2}{c|}{ C. glabrata ATCC 90030 } & \multicolumn{2}{c|}{ C. parapsilosis ATCC22019 } \\
\hline & MIC & MFC & MIC & MFC & MIC \\
\hline $\mathbf{5 a}$ & 0.62 & 1.54 & 1.22 & 3.25 & 0.85 \\
\hline $\mathbf{5 b}$ & 0.84 & 2.16 & 2.36 & 5.60 & 1.74 \\
\hline $\mathbf{5 c}$ & 2.56 & 6.23 & 3.42 & 6.84 & 2.32 \\
\hline $\mathbf{5 d}$ & 1.88 & 4.50 & 3.12 & 6.25 & 52 \\
\hline
\end{tabular}

Positive control with Amphotericin B (MFC $0.5 \mu \mathrm{g} / \mathrm{ml}$ )

Table 6: Antifungal MIC (mg/ml) and MFC ( $\mathrm{mg} / \mathrm{ml})$ of compounds $\mathbf{5 a}, \mathbf{5 b}, \mathbf{5 c}$ and $\mathbf{5 d}$

Either at low concentrations, these compounds showed an interesting anticandidal activity.

In conclusion, our results indicate that compounds $5 \mathrm{a}$ and $5 \mathrm{~b}$ have potential anti-inflammatory and analgesic effects associated with antifungal and gastroprotective properties against $\mathrm{HCl} /$ ethanol induced gastric ulcer. The mechanism of $5 \mathrm{a}$ and $5 \mathrm{~b}$ mediated protection may be related to decreases in free radical production. These observations raise the possibility of compounds $5 \mathrm{a}$ and $5 \mathrm{~b}$ being used to treat inflammation and to improve resistance to gastric mucosal injury.

\section{References}

1. Hajhashemi V, Sajjadi SE, Heshmati M (2009) Anti-inflammatory and analgesic properties of Heracleum persicum essential oil and hydroalcoholic extract in animal models. J Ethnopharmacol 124: 475-480.

2. Ngo DH, Wijesekara I, Vo TS, Ta QV, Kim SK (2011) Marine food-derived functional ingredients as potential antioxidants in the food industry: an overview. Food Res Int 44: 523-529.

3. Ngo DH, Vo TS, Ngo DN, Wijesekara I, Kim SK (2012) Biological activities and potential health benefits of bioactive peptides derived from marine organisms. Int J Biol Macromol 51: 378-383.

4. Weitzel KW, Wickman JM, Augustin SG, Strom JG (2000) Zaleplon: a pyrazolopyrimidine sedative-hypnotic agent for the treatment of insomnia. Clin Ther 22: 1254-1267.

5. Gupta S, Rodrigues LM, Esteves AP, Oliveira-Campos AMF, José Nascimento $\mathrm{MS}$, et al. (2008) Synthesis of $\mathrm{N}$-aryl-5-amino-4-cyanopyrazole derivatives as potent xanthine oxidase inhibitors. Eur J Med Chem 43: 771-780.

6. Allouche F, Chabchoub F, Carta F, Supuran CT (2013) Synthesis of aminocyanopyrazoles via a multi-component reaction and anti-carbonic anhydrase inhibitory activity of their sulfamide derivatives against cytosolic and transmembrane isoforms. J Enzyme Inhib Med Chem 28: 343-349.

7. Kim JK, Noh JH, Lee S, Choi JS, Suh H, et al. (2002) The first total synthesis of 2,3,6-tribromo-4,5-dihydroxybenzyl methyl ether (TDB) and its anti-oxidant activity. Bull Korean Chem Soc 23: 661-662.

8. Zaouali Y, Bouzaine T, Boussaid M (2010) Essential oils composition in two Rosmarinus officinalis L. varieties and incidence for antimicrobial and antioxidant activities. Food Chem Toxicol 48: 3144-3152.

9. Deghrigue M, Festa C, Ghribi L, D’Auria MV, De Marino S, et al. (2014) Pharmacological evaluation of the semi-purified fractions from the soft coral
Eunicella singularis and isolation of pure compounds. DARU J Pharm Sci 22: 64 .

10. Ayed Y, Dellai A, Ben Mansour H, Bacha H, Abid S (2012) Analgesic and antibutyrylcholinestrasic activities of the venom prepared from the Mediterranean jellyfish Pelagia noctiluca (Forsskal, 1775). Ann Clin Microbio Antimicrob 11: 15

11. Hammer KA, Carson CF, Riley TV (1999) Antimicrobial activity of essential oils and other plant extracts. J Appl Microbiol 86: 985-990.

12. Petrie CR 3rd, Cottam HB, McKernan PA, Robins RK, Revankar GR $(1985)$ Synthesis and biological activity of 6-azacadeguomycin and certain 3,4,6-trisubstituted pyrazolo[3,4-d]pyrimidine ribonucleosides. J Med Chem 28: 1010-1016.

13. Anderson JD, Cottam HB, Larson SB, Nord LD, Revankar GR, et al. (1990) Synthesis of certain pyrazolo[3,4-d]pyrimidin-3-one nucleosides. J Heterocycl Chem 27: 439-453.

14. Aggarwal R, Kumar V, Kumar R, Singh SP (2011) Approaches towards the synthesis of 5-aminopyrazoles. Beilstein J Org Chem 7: 179-197.

15. Booth BL, Costa FAT, Mahmood Z, Pritchard RG, Proença MF (1999) Synthesis of (Z)-N-(2-amino-,2-dicyanovinyl) formamide O-alkyloximes and a study of their cyclisation in the presence of base. J Chem Soc Perkin Trans 1 13: $1853-1858$.

16. Oliveira-Campos AMF, Salaheldin AM, Rodrigues LM (2007) Synthesis of some novel pyrazolo[3,4-d]pyrimidine derivatives. Arkivoc 16: 92-100.

17. Bakavoli M, Bagherzadeh G, Vaseghifar M, Shiri A, Pordel M, et al. (2010) Molecular iodine promoted synthesis of new pyrazolo[3,4-d]pyrimidine derivatives as potential antibacterial agents. Eur J Med Chem 45: 647-650.

18. Zhang HY, Yang DP, Tang GY (2006) Multipotent antioxidants: from screening to design. Drug Discov Today 11: 749-754.

19. Shimada K, Fujikawa K, Yahara K, Nakamura T (1992) Antioxidative properties of xanthan on the autoxidation of soybean oil in cyclodextrin emulsion. J Agric Food Chem 40: 945-948.

20. Yonathan M, Asres K, Assefa A, Bucar F (2006) In vivo anti-inflammatory and anti-nociceptive activities of Cheilanthes farinosa. J Ethnopharmacol 108: 462-470.

21. Woldesellassie M, Eyasu M, Kelbessa $U$ (2011) In vivo anti-inflammatory activities of leaf extracts of Ocimum lamiifolium in mice model. J Ethnopharmacol 134: 32-36.

22. William CM, Rao NV, Kumar BR, Mohan GK (2010) Anti-inflammatory and analgesic activities of methanolic extract of Kigelia pinnata DC flower. J Ethnopharmacol 130: 179-182. 
Citation: Karoui A, Deghrigue M, Kirsch G, Bouraoui A, Chabchoub F, et al. (2016) Synthesis and Biological Activities of Novel 1,7-dihydropyrazolo[3,4- $d$ ] imidazo[1,2-f]pyrimidines. Med chem (Los Angeles) 6: 157-164. doi:10.4172/2161-0444.1000340

23. Panthong A, Supraditaporn W, Kanjanapothi D, Taesotikul T, Reutrakul V (2007) Analgesic, anti-inflammatory and venotonic effects of Cissus quadrangularis Linn. J Ethnopharmacol 110: 264-270.

24. Matsumoto T, Moriguchi R, Yamada H (1992) Role of polymorphonuclearleucocytes and oxygen-derived free radicals in the formation of gastric lesions induced by $\mathrm{HCl} / \mathrm{ethanol}$, and a possible mechanism of rotection by antiulcer polysaccharide. J Pharm Pharmacol 45: 535-539.

25. Collier HO, Dinneen LC, Johnson CA, Schneider C (1968) The abdominal constriction response and its suppression by analgesic drugs in the mouse. $\mathrm{Br}$ J Pharmacol Chemother 32: 295-310. 